\title{
THE TEACHERS' PERSPECTIVES TOWARDS THE LITERACY PROGRAM DEVELOPED AT A BILINGUAL SCHOOL
}

\author{
Putu Santi Oktarina \\ Institut Hindu Dharma Negeri Denpasar \\ putusantioktarina@gmail.com
}

\begin{abstract}
There can be multiple sorts of bilingual education, they depend on how the two languages are taught, on the teaching goals and on the teachers. Moreover, it is on the pupils, methods, state policy and society's attitude towards bilingualism. Dyatmika school is an example of a bilingual school in Bali. Dyatmika School (Sekolah Dyatmika) is currently in its $17^{\text {th }}$ year of operation and has grown to offer a rich educational programme in English and Indonesian to children from the age of 3 to 18. The Primary School of Dyatmika School covers classes 1 to 6 and has a dual language program of Indonesian and English. English literacy has been done for years, but intensive Indonesian literacy has just been done for a year and a half. It can be said that this bilingual literacy program has just started for 1.5 years. It is important to see the perspective of the teachers towards the bilingual literacy program run in Dyatmika School. This study used a descriptive qualitative design. The research subjects of the present study were the national teachers of Dyatmika school. The subjects were class teachers and one was a substitute teacher. Based on the research conducted, there are two main results, namely (1) there are four biliteracy programs done by Dyatmika School involving reading aloud, shared reading, guided reading, and home reading. (2) According to the local teacher's perspective, the biliteracy program applied in Dyatmika is beneficial for the students as well as for the teachers. The correlation between both languages in which they are presenting a similar topic but in a different way make the students get a deeper understanding of the topic.
\end{abstract}

Keywords: Teachers' Perspectives, Literacy Program, Bilingual School

\section{INTRODUCTION}

Bilingualism is a word that has been used to define the quality of individual children as well as social institutions. At both levels, the issue has been overshadowed by controversy. On the individual level, the debate has intensified on the potential costs and advantages of bilingualism in young children, On the societal level, a fiery argument can be seen in the United States concerning the wisdom of bilingual education and the official support of languages other than English in public institutions. Particularly in the latter case, emotions run hot because of the symbolism included in language and its correlation with ethnic group membership. Bilingual 
education remains to debate in the national as well as local arenas. Some consider intensely that the use of any language other than English in the U.S. generates divisiveness; others believe that freedom to speak whatever language one wishes is a major human right. Yet others assume that other languages in education are an extravagance that cannot be sustained in difficult economic times. As current demographic projections show, the number of children labeled as limited English proficient (LEP) will remain to increase; therefore, bilingual education is likely to continue to be a topic of debate. In order to know the contentiousness of this matter, it may be necessary to shortly examine assumptions and questions carrying some of the more generally linked arguments associated with bilingual education. First, several appeals to national unity as a principal reason to refuse bilingual education. A fairly passionate view relates to language rights and notes that as the Constitution does not endorse one religion, neither does it proclaim one language. A third perspective is that bilingual education is a generous attempt to help less fortunate nonnative English speakers that simply is not affordable in difficult economic times. Common to all three of these divergent views is the assumption that bilingual education is intended to promote bilingualism, and that it does, in fact, produce students who are either bilingual or whose English is less developed than that of their native English-speaking peers. Both assumptions can be challenged; bilingual programs are so diverse that it is problematical to make generalizations. In fact, efforts to review the efficacy of bilingual education programs, the most famous example of which is the AIR report (Hakuta, 1986), are criticized for failing to take into account the significant variations in programs. Labeling a program as transitional bilingual education, for example, does not ensure that the program is transitional nor that it is bilingual. The students served, languages spoken, grades and ages involved, number of teachers, their specializations and languages, subject matter taught, hours in the program, and so on are all variables that make each program distinct. The program descriptions in this issue demonstrate this very well.

Technically, any educational system that utilizes more than one language is bilingual. This means that many, if not most, school programs are bilingual, in at least a literal sense of the word. What differentiates various programs that are labeled as 'bilingual' is the degree to which multiple languages are used. Bilingualism is an opportunity, not an obstacle to literacy. Bilingualism not only does not appear to be an obstacle to literacy development in either language, but also seems to provide the learner with heightened skills necessary for literacy. Instruction and content which fail to fully consider the role of language development, especially bilingualism, or the relevance of 
learning activities and materials to the lived experiences of the learner, at this point, seem to be the major obstacles to literacy development among bilingual students. Given the critical role of language proficiency to literacy development, it follows that successful literacy programs for bilingual students are more likely to occur within the context of a strong language development program.

Dyatmika school is an example of bilingual school in Bali. Dyatmika School (Sekolah Dyatmika) is currently in its $17^{\text {th }}$ year of operation and has grown to offer a rich educational programme in English and Indonesian to children from the age of 3 to 18. The Primary School of Dyatmika School covers classes 1 to 6 , and has a dual language program of Indonesian and English. This dual language approach means that children have the opportunity to gain proficiency in both Indonesian and English in listening, speaking, reading and writing in all areas of the academic curriculum. To be successful in English and Indonesian, the students in Dyatmika were given a literacy program which started from year 3 to 12.

The English literacy has been done for years, but an intensive Indonesian literacy has just been done for a year and a half. It can be said that this bilingual literacy program has just started for 1.5 years. It is important to see the perspective of the teachers towards the bilingual literacy program run in Dyatmika School. Because of that, this mini research was aiming at describing the program run by Dyatmika School and the teachers' perspective towards the program. Further, it is expected that another research can be conducted after this mini research design bilingual literacy program for another school especially for public schools. It aims at describing the programs run by Dyatmika School as a bilingual school in developing students' literacy in both languages Indonesian and English and describing the teachers' perspectives towards the programs run by Dyatmika School as a bilingual school.

This research was limited in investigating the literacy program for year 3 to 12 run by Dyatmika school. The data collection was done in Dyatmika School as one of bilingual school in Bali. Moreover, the focuses of this research are describing the literacy program in Dyatmika School for both languages; English and Indonesia and identifying teachers' perceptions towards the literacy program in Dyatmika School including identifying teachers' perception towards four basic things (context, input, process, and product). Because of that, in this mini research, the teachers' perception will be limited to describe the context, input, process, and product.

\section{DISCUSSION}

\subsection{Bilingual Education}

\subsubsection{Definition of Bilingual Education}

According to Slavin (2009), the term bilingual education refers to 
programs for students who are acquiring English that teach the students in their first language part of the time while English is being learned.

Bilingual education also defines as teaching students in their native languages to develop socio academic literacy and ways of talking about the various content area of interest in school and society, while they are integrated into the same content area in English as they progress into school (Faltis and Hudelson, 1998).

Bilingual education has been practiced in many forms, in many countries, for thousands of years. Defined broadly, it can mean any use of two languages in school - by teachers or students or both - for a variety of social and pedagogical purposes. The main purpose of bilingual education is giving language skills including listening, reading, speaking, and writing in any language other than the students' mother tongue.

Bilingual education models are described broadly according to their goals, type of students served, languages in which literacy is developed, and languages of subject matter instruction. Bilingual education models are divided between those that have as a major goal fluency in two languages and those that strive for fluency in the second language. The first type has no limitations in the number of years a student can attend; it can include a program within a school or the whole school can be bilingual. Dual- language schools, two-way bilingual education, maintenance bilingual education, and bilingual programs for the deaf are included in this category. The second type, which includes transitional bilingual education (TBE), pull-out TBE, integrated TBE, and bilingual structured immersion, shares the goal of preparing students to function in monolingual classes (Brisk, 2008).

- Dual-Language Schools

- Two-Way Bilingual Education

- Maintenance Bilingual Education,

- Bilingual Programs For The Deaf

- Transitional Bilingual Education (TBE)

- Pull-Out TBE

- Integrated TBE

\subsubsection{The Bilingual Child}

In the calculus of mental energy, what are the costs of bilingualism? Early research on the effects of bilingualism on immigrant children, conducted primarily at the turn of the century. painted a bleak picture. As Thompson (1952) wrote in summarizing this body of literature, "There can be no doubt that the child reared in a bilingual environment is handicapped in his language group. One can debate the issue as to whether speech facility in two languages is worth the consequent retardation in the common language of the realm" (p. 367).

Much of this earl? work on bilingualism in children can be interpreted within the context of the 
social history surrounding the debate over the changing nature of immigration in the early 1900s. The basic data to be explained were bilingual children's poor performances on various standardized tests of intelligence. From the empiricist point of view, the bilingualism of the children was thought to be a mental burden that caused lower levels of intelligence. This viewpoint was offered as an alternative to the hereditarian position, argued forcefully by prominent nativists such as Carl Brigham, Lewis Terman, and Florence Goodenough, that the new immigrants were simply from inferior genetic stock (Hakuta, 1986). Subscribers to the latter viewpoint sounded the social alarm that "these immigrants are beaten men from beaten races, representing the worst failures in the struggle for existence. Europe is allowing its slums and its most stagnant reservoirs of the degraded peasantry to be drained off upon our soil" (Francis Walker, quoted in Ayres, 1909. p. 103).

What is interesting about this early literature is its definition of bilingualism. The bilingual children included in these studies were not chosen on the basis of their linguistic abilities in the two languages. Rather, societal level criteria having to do with immigrant status were used, such as having a foreign last name (see Diaz, 1983). It is not clear whether the "bilingual" children in these studies were at all bilingual in their home language and English. Yet, on the basis of such studies using social rather than linguistic criteria, conclusions were drawn as to the effects of linguistic variables on intelligence. The point here is that language is a salient characteristic of children from immigrant and minority backgrounds that provides an opportune dumping ground for developmental problems that may or may not be related to language.

Research in the last few decades, fortunately, has developed considerable sophistication in understanding second-language acquisition and the nature of bilingualism. What has emerged is a relatively consistent set of answers to some fundamental questions about the linguistic and cognitive development of bilingual children. These answers argue against the early view-still held to be fact by some laypersons and educators-that bilingualism could be harmful to the child's mental development and that the native language should be eliminated as quickly as possible if these effects are to be avoided.

Indeed, more recent studies suggest that all other things being equal, higher degrees of bilingualism is associated with higher levels of cognitive attainment (Diaz. 1983). Measures have included cognitive flexibility, metalinguistics awareness, concept formation, and creativity. These findings are based primarily on research with children in additive bilingual settings, that is. in settings where the second language is added a an enrichment to the native language and not at the expense of the native language. Causal 
relationships have been difficult to establish. but in general, positive outcomes have been noted. particularly in situations where bilingualism is not a socially stigmatized trait but rather a symbol of membership in a social elite.

\subsubsection{Second-Language Acquisition}

An important theoretical justification for the early view about the compensatory relationship between the two languages can be found in behaviorist accounts of language acquisition. If firstlanguage acquisition consists of the establishment of stimulus-response connections between objects and words and the formation of generalizations made on the basis of the frequency patterns of words into sentences, then second-language acquisition must encounter interference from the old set of connections to the extent that they are different. The two languages were seen, in this empiricist account, as two sets of stimuli competing for a limited number of connections. This provided justification for the advice given to immigrant parents to try and use English at home so as not to confuse the children.

This empiricist account of language acquisition was strongly rejected in the late 1950s and 1960s on both theoretical (Chomsky, 1957) and empirical grounds (Brown \& Bellugi, 1964). As with most revolutionary changes in the empirical disciplines, the nature of the questions about language acquisition changed in a qualitative manner. The new metaphor for the acquisition of language was the unfolding of innate capacities, and the goal of research became to delineate the exact nature of the unfolding process. If language acquisition was not the forging of connections between the stimuli of the outside world, then one would no longer have to see the learning of a second language as involving a "dogeat-dog," competition with the first language. To borrow James Fallows's (1986) recent metaphor, having two languages is more like having two children than like having two wives.

There is considerable research support for this more recent view. For example, in the process of second-language acquisition, the native language does not interfere in any significant way with the development of the second language. Second-language acquisition and first-language acquisition are apparently guided by common principles across languages and are part of the human cognitive system (McLaughlin, 1987). From this structural point of view, the learning of a second language is not hampered by the first. Furthermore, the rate of acquisition of a second language is highly related to the proficiency level in the native language, which suggests that the two capacities share and build upon a common underlying base rather than competing for limited resources (Cummins, 1984).

\subsubsection{Factors that influence bilingual education}


Based on Brisk (2008, p. 96135), a good school that conducting bilingual education program should have some criteria, such as has clear goals, appropriate school climate, integrate the bilingual program into the school community, provide leadership and support for the bilingual program, hire quality personnel willing and prepared to work with bilingual students, establish productive partnerships with parents and communities of the bilingual, good curricula, and instructions.

\section{a) School's goals}

Administrators need to clarify goals for all their students. This enables schools to develop coherent curricula and consistent language policies, motivate and assess teachers, and stimulate the involvement of their communities in providing constructive criticism and support. School goals for bilingual students must be understood and shared by all students, and their families.

\section{b) School's climate}

Effective schools establish an orderly and safe climate (Montecel \& Cortez, 2002 in Brisk, 2008, p. 100). In schools where there are students of other cultures, an essential ingredient for a safe school climate is respect for languages and cultures. In addition, language acquisition is enhanced when both languages have equal status, are spoken by individuals, important to the students, and are necessary for communication in a variety of social environments (Senesac, 2002). Bilingual students need to feel that their school is a community that cares for them, treats them as individuals, and wants them to succeed (McPartland \& Braddock, 1993 in Brisk, 2008, p. 100).

\section{c) Leadership and Support for the Bilingual Program}

Administrators must support the bilingual program, its teachers, and its students. They must understand the conditions for quality bilingual education, foster collaboration among teachers, and gain community support and participation.

\section{d) Quality of Personnel}

Educating and caring for bilingual students requires strong commitment and energy. This commitment extends beyond the classroom and lasts over years. Personnel with the will to educate students monitor quality of instruction, embrace innovation, and persist in their commitment to students and to improving education. They do not despair in the presence of difficult situations and find ways to change them.

Personnel working in schools with bilingual students need to combine commitment, leadership, and preparation to create the appropriate school environment, to develop quality curriculum, and to implement instructional strategies conducive to learning. Their willingness to provide a good education sets the tone of the school 
and invigorates students often discouraged by experiences in the larger society.

\section{e) Relationships with the Parents and Communities of the Students}

Parental participation in the education of children is critical for successful education. The types of home-school partnerships vary and so do the results. Communication between school personnel and families improves students' reading achievement (Snow, Barnes, Chandler, Goodman, \& Hemphill, 1989 in Brisk, 2008), helps students feel enthusiastic about their education, and helps teachers better understand the culture of the home (Ruiz, 1993 in Brisk, 2008). Parental participation in family literacy programs results in increased parental involvement in community and educational activities affecting them and their children (Ada, 1988; Delgado-Gaitán, 1991 in Brisk, 2008). Participation in the governance of the school increases parental support for school goals (Carter \& Chatfield, 1986 in Brisk, 2008). The more diverse the connections are, the broader the benefits will be (Goldenberg, 1993 in Brisk, 2008).

\section{f) Curricula}

Brisk (2008, p 136-163) also states that a good bilingual school should have a good quality of curricula. A curriculum of bilingual school should have these criteria:

(1) The curriculum should be bilingual, meaning that: $\checkmark$ the native language should be used for an extended number of years to develop literacy and for teaching academic content,

$\checkmark$ English, the second language (L2), should be fully developed,

$\checkmark$ languages are used to maximize instruction,

$\checkmark$ language choice and student assignments should be consistent.

(2) The curriculum should be cross-cultural, meaning that:

$\checkmark$ native culture is included,

$\checkmark$ personal experiences are tapped,

$\checkmark$ local culture is explicitly taught, and

$\checkmark$ cultural conflicts are analyzed.

(3) All bilingual students should participate in a comprehensive and quality curriculum, meaning that:

$\checkmark$ All content areas are covered.

$\checkmark$ Content, language, and culture are integrated.

$\checkmark$ Thinking and study skills are explicitly taught.

$\checkmark$ Materials should be varied, of high quality, interesting, and in the native languages as well as English.

$\checkmark$ Content and language assessment should be ongoing, authentic, and fair.

\section{g) Instructions}


Beside curricula, a good bilingual education should consider the quality of its instruction (Brisk, 2008, p. 164198). A good instruction should have these criteria:

- Instruction should respect students, their language, and their culture.

- Instruction should be engaging, challenging, and supportive.

- Special strategies are needed for teaching English and teaching in English.

- Special consideration should be given to students with limited literacy and schooling.

- Class objectives should include language, culture, and academic content.

- Students should play an active role in learning.

- Classrooms should be organized to maximize learning, collaboration, and participation.

- Assessment should be integrated with instruction.

- Resources should be varied and serve the basic goals.

- Family and communities should be partners in the classroom.

- Teachers should maximize their skills and backgrounds.

\section{Research Methods}

This study is using a descriptive qualitative design. The research subjects of the present study were the national teachers of Dyatmika school. The subjects were class teachers and one was a substitute teacher. The class teachers were chosen because these teachers would stay in the class in Indonesia and English time, especially for group reading (one of the literacy programs). A substitute teacher was chosen since she was helping classes in doing group reading both in English and Indonesian. Meanwhile, the research objects were involving the description of biliteracy program in Dyatmika School and any legal documents about it. Besides, the teachers' perception became another research object. However, to get complete data about the biliteracy program, both primary international and national principals were interviewed. The data were collected throughout interview, observation, and document analysis.

Further, the data will be analyzed in using Miles and Huberman model. Miles and Huberman model consists of four steps, such as data collection, data reduction, data display and conclusion drawing/verification. Those steps is done to obtain the desired pattern so that can be drawn a conclusion.

\section{Research Findings}

\subsection{The Literacy Program done by Dyatmika School}

Before analyzing the data, the profile of Dyatmika School was descrinbed at first. Dyatmika school is one of bilingual school in Bali 
located on Jalan Pucuk Bang, Banjar Tangtu Kesiman Denpasar Timur. It was built in 1995 by some parents. Dyatmika is using two-way immersion for their bilingual program. It means that the proportion of English and Indonesian are given in the same amounts. Also, this school is using alternate time to have the students use and get the language equally in the class. There are two kinds of teachers in each class, apart from the specialist teachers who teach special programs, they are an international teachers who handled two classes in turns and a national class teacher.

Data about biliteracy program executed by Dyatmika school were gained by doing interview with the principals, both international Principal (April Collet) and national principal (Ayu Sugati) on Friday, January $18^{\text {th }} 2013$. There was no any written documents which regulate the biliteracy program in Dyatmika school. However, planning format was provided as well as the developmental skill continuum (guidance to assess the students' biliteracy).

According to interview with the principals, the rationale of having biliteracy program in Dyatmika is due to the purpose of the school as a bilingual school. Here the statement of the international principal about the rationale of the biliteracy program emergence:

...We want to bridge the need of the students whether they have Indonesian as a second language or English as a second language. The biliteracy program will help them to develop the students' literacy need in both languages...[...] The bilingual school aims at having the students become professionally bilingual, academically bilingual, and literary bilingual...

Based on the statement above, it can be clearly seen that Dyatmika as a bilingual school commits to have the students gain that three targets and the biliteracy program will help them to reach those goals.

In Dyatmika Primary School, the literacy program was started from the kindergarten until class six. However, for the kindergarten level, a special method was used which was well known as Jolly Phonics Program. This program helps the students to have phonological awareness as a strong foundation to start learning literarily. In Jolly Phonics program there five basic stages before the students are ready to read. They are learning the letter sounds, learning letter formation, blending, identifying sounds in words, and spelling irregular or 'tricky' words (said, was, the etc.).

Another findings based on the interview with the principals were found. There were four literacy agreements between Indonesian and English which are developed by Dyatmika School, as stated by the international principal below. 
...There are four literacy

agreements which become

the major concerns for the

development of biliteracy

program in this school.

They are reading aloud,

guided reading, shared

reading, and home

reading...

Based on the observation, those programs have been started already in TK B, except the guided reading. Meanwhile in TK $A$, they have just start with shared reading. All those four programs are planned to be executed starting from class 1 . It is in line with the principal's statement who said that the four programs will run effectively in class 1 and above.

Based on the observation, those four biliteracy programs can be described as follows.

1. Reading aloud

Reading aloud in this school context is a teacher will stand or sit down in front of the class and the students are sitting down on the carpet. She or he is holding a book and reading that book aloud. Based on the observation, reading aloud aims at introducing vocabulary, providing a model of fluent, showing expressive reading, and helping children recognize what reading for pleasure is all about. In this school, reading aloud is mostly used by the teacher for introducing new topics.

2. Guided reading
Before doing a guided reading, the students were assessed first. Then, the teachers divide them into four groups based on their reading level. However, the teacher did not say to the children that groups were classified based on their reading level. Every group is handled by one teacher. This teacher brings a bag of books. Every student in the group will get the book. They will read the books in turns. Here the teacher can control the students closer. Because of that it was said a guided reading since the teacher guide them during the reading activities. After reading the book, students are given several tasks or worksheets by the teacher to have them really understand about the content of the text.

3. Shared reading

Shared reading in the kindergarten classroom (including TK A and TK B) consisted of echo reading (students are echoing the words after the teacher), choral reading (students reading at the same time as the teacher), or fill in the gap reading (teacher is reading the majority of the text and then pausing for students to fill in and say rhyming words or other predictable words in the story).

Shared reading in both in kindergarten and primary is 
using big books to show. The content of the book will be discussed together with the students. The students can read the book from their spot since the size of the book is big.

4. Home reading

Here the students will be given a book to take home every day, except Friday. The level of the book is also adjusted to the students' reading level. Every day, they will have two books home, English and Indonesian. The students are also given an agenda, and they need to write the title of the book in the agenda. Here, the parents are expected to be able to help the students and assist them in reading.

According to the principals, the school and the PTFA (Parents, Teachers, and Friends of Dyatmika Association) strongly support this program especially for developing the Indonesian literacy. For years, Indonesia did not have sufficient and appropriate books for the kids to read. In contrast with English which are really complete with various level of books. The students were given the books based on their reading level. In short, the students were given materials which are not too difficult for them to understand so they can learn in a joyful way.

The biliteracy program also involves BIPA (Bahasa Indonesia bagi Penutur Asing) and ESL
(English as a Second Language). This program was addressed to any students who are very low in Bahasa Indonesia or English. This program was directly guided by the principals.

She also added that since the previous year, Dyatmika is developing some books with various levels which can be used for Indonesian literacy. The school and PTFA supported this program by providing an amount of budget to buy and to make appropriate books as the English one. The principals have asked several national teachers to be included in a book committee. They will be responsible to create books, edit them, and try them out in the class, until the books ready to be used. The Indonesian literacy adapted the English literacy, for example for the book characteristics, assessment, and the developmental reading continuum (see enclosure).

\subsection{The National Teachers' Perception towards the Biliteracy Program Done by Daytmika School}

There are four national teachers being interviewed to see their perception towards the bilitercy program. They were chosen because they were involved in both literacy program English and Indonesian. It is different from the expatriate teachers who handled the English literacy program only.

The teachers' perceptions towards the biliteracy program were involving four major aspects about the program. They are context, input, process, and product. The interview 
questions were made based on these four aspects.

Here are the subjects of the research:

1. I Wayan Sudiarta, S.Pd.(TK A teacher)
2. Ni Komang Dwi Eka Yuliani, S.Pd.(Class 1 teacher)

3. Nyoman Sulistiari, S.Pd.(Substitute teacher)

4. Luh Putu Kusumadewi Yuliani, S.Pd(Class 5 teacher)

Table 1 Summary of Teachers' Perception towards the Biliteracy Program

\begin{tabular}{|c|c|c|c|c|}
\hline \multirow{2}{*}{ Subjects } & \multicolumn{4}{|c|}{ Teacher's Perception towards the Biliteracy Program } \\
\hline & Context & Input & Process & Product \\
\hline $\begin{array}{l}\text { IWayan } \\
\text { Sudiarta, } \\
\text { S.Pd. }\end{array}$ & $\begin{array}{l}\text { The } \\
\text { purpose is } \\
\text { to } \\
\text { introduce } \\
\text { that } \\
\text { words } \\
\text { have } \\
\text { meaning } \\
\text { and } \\
\text { sounds }\end{array}$ & $\begin{array}{l}\text { For English } \\
\text { the school } \\
\text { provide } \\
\text { Jolly } \\
\text { Phonics } \\
\text { program } \\
\text { from } \\
\text { Britain, } \\
\text { but in } \\
\text { Indonesia } \\
\text { n, a very } \\
\text { limited } \\
\text { resources } \\
\text { are } \\
\text { provided } \\
\text { My friends } \\
\text { and I } \\
\text { should } \\
\text { adapt the } \\
\text { Jolloy } \\
\text { Phonics } \\
\text { Program } \\
\text { into } \\
\text { Indonesia } \\
\text { n }\end{array}$ & $\begin{array}{l}\text { For } \\
\text { Indonesian } \\
\text { program, I } \\
\text { need more } \\
\text { games and } \\
\text { books for } \\
\text { the } \\
\text { students to } \\
\text { explore } \\
\text { I did parent } \\
\text { workshop } \\
\text { to show } \\
\text { them how } \\
\text { to help their } \\
\text { kids at } \\
\text { home } \\
>\text { I inform } \\
\text { more on the } \\
\text { teacher- } \\
\text { parent } \\
\text { conference, } \\
\text { open day } \\
\text { The students } \\
\text { love Jolly } \\
\text { Phonics } \\
\text { program } \\
\text { since they } \\
\text { learn in fun } \\
\text { ways }\end{array}$ & $\begin{array}{l}\text { The } \\
\text { students } \\
\text { did not } \\
\text { feel under } \\
\text { pressure } \\
\text { when they } \\
\text { are } \\
\text { learning } \\
\text { literacy } \\
\text { Students } \\
\text { also } \\
\text { remember } \\
\text { all the } \\
\text { motion of } \\
\text { each } \\
\text { sound } \\
\text { that } \\
\text { construct } \\
\text { words } \\
\text { which is } \\
\text { very good } \\
\text { as a } \\
\text { strong } \\
\text { basic for } \\
\text { reading } \\
\text { and } \\
\text { writing }\end{array}$ \\
\hline $\begin{array}{l}\text { Ni Komang } \\
\text { Dwi Eka }\end{array}$ & $\begin{array}{l}>\text { The } \\
\text { purpose is }\end{array}$ & $\begin{array}{l}>\text { The } \\
\text { support }\end{array}$ & $\begin{array}{l}\text { Students are } \\
\text { more }\end{array}$ & $\begin{array}{l}\text { Students } \\
\text { show }\end{array}$ \\
\hline
\end{tabular}




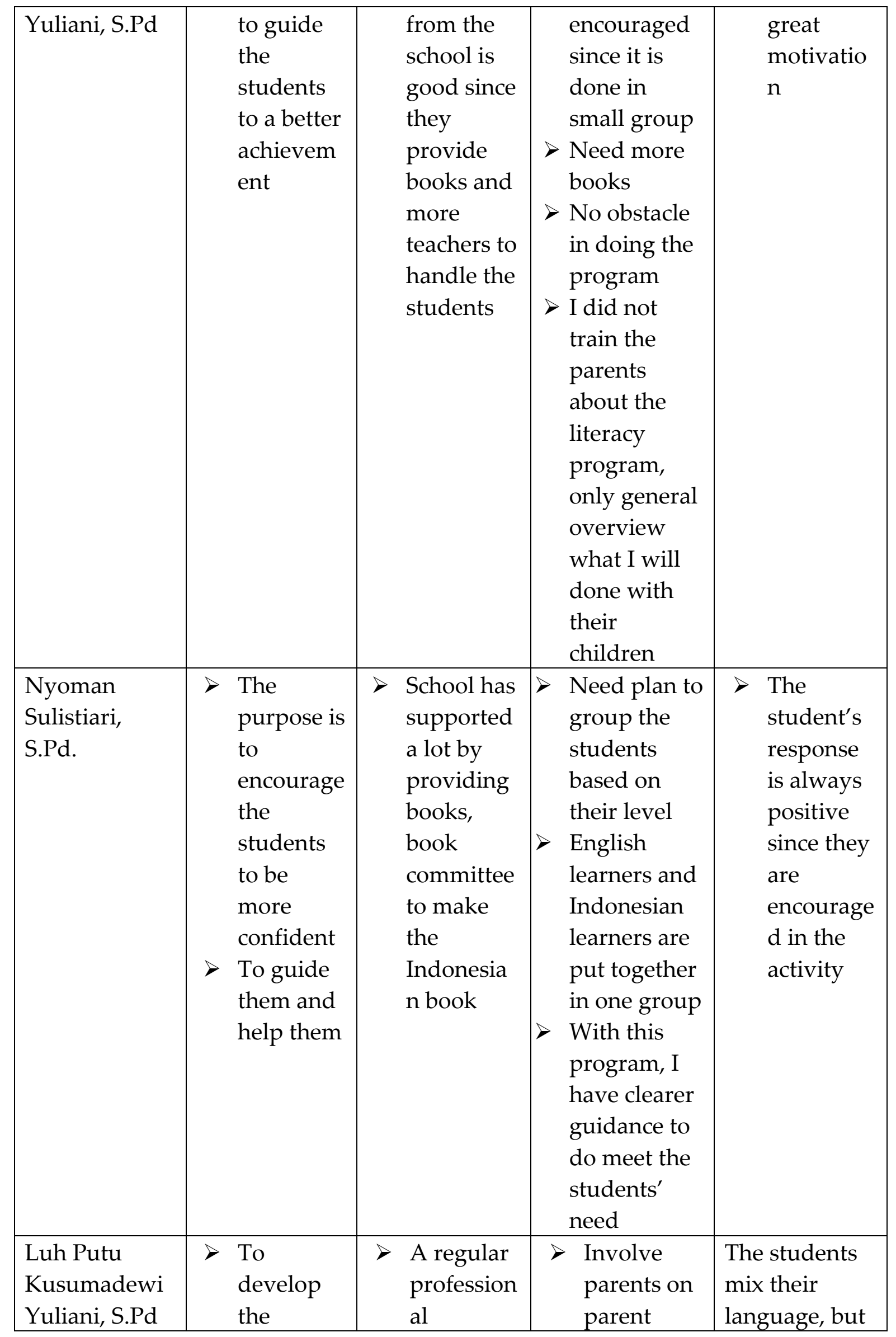




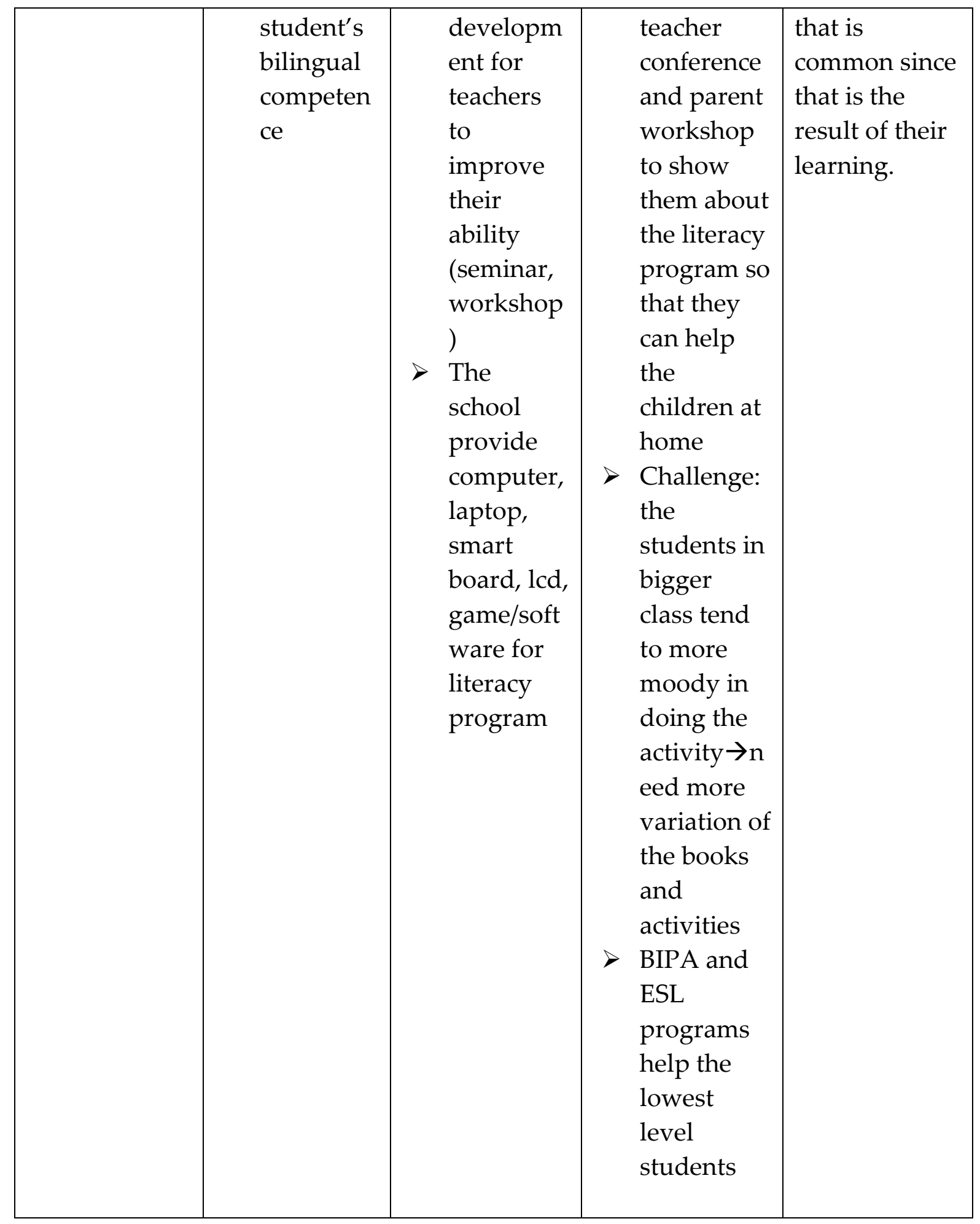

Based on the summary above, it can be said that the biliteracy program is very beneficial for both teachers and students since the teacher can guide the students intensively and the students are also more encouraged during the activity. The support of the school and PTFA have been shown by their support in funding the Indonesian book making. Besides, the principals held a professional development to improve the 
teacher's ability in handling the program. The students give a positive response according to the teachers' observation during the literacy program.

The challenge faced by the teachers mostly in terms of input and process. As the previous explanation, the limited books and resources especially for Indonesian literacy contribute to the need of improvement in term of the input of the program. Meanwhile, some teachers did not concern the parents' involvement in the program. They did not design any activities to involve the parents. It means that the process of the program should be improved.

\section{CONCLUSION}

Based on the research conducted, there are two main main results, namely (1) there are four biliteracy programs done by Dyatmika School involving reading aloud, shared reading, guided reading, and home reading. (2) According to the local teacher's perspective the biliteracy program applied in Dyatmika is beneficial for the students as well as for the teachers. The correlation between both languages in which they are presenting similar topic but in different way make the students get deeper understanding about the topic. Actually, the four biliteracy programs of Dyatmika School which involve reading aloud, shared reading, guided reading, and home reading, can be adapted by other schools eve public schools. It is suggested that further research can evaluate this literacy program from the parents' and students' perspectives.

\section{REFERENCES}

Bax, Stephen. 2010. Researching English Bilingual Education in Thailand, Indonesia, and South Korea. British Council.

Brisk, Maria. 2008. Bilingual Education : From Compensatory to Quality Schooling.The Taylor \& Francis e-Library.

Chen, Sylvia Xiaohua, Veronica Benet-Martinez, and Sylvia Xiaohua. (2008). Bicultural Identity, bilingualism, and Psychological Adjustment in Multicultural Societies: Immigration-Based and Globalization-Based

Acculturation. Journal of Personality 76:4.

Cortés, C. (1986). The education of language minority students: A contextual interaction model. In Bilingual Education Office, beyond language: Social and cultural factors in schooling language minority students (pp. 3-33). Sacramento: California State Department of Education.

Dobson, Alan. Et.al. 2010. Bilingual Education Project Spain Evaluation Report. British Council.

Gall, M.D., Gall, J.P, and Borg, W.R.2003. Educational Research (I). An Introduction. Seventh Edition. United 
States of America : Pearson

Education, Inc.

Grosjean, F. (1999). Individual bilingualism. In B. Spolsky (ed.), Concise Encyclopedia of Educational Linguistics, pp. 284-90. London: Elsevier.

Hornberger, Nancy H. (2004)The Continua of Biliteracy and the Bilingual Educator: Educational Linguistics in Practice. International Journal of Bilingual Education and Bilingualism, Volume 7, Issues 2\&3, pages 155-171.

Lodico, Marguerite G. 2010. Method in

Educational Research: From Theory to Practice. Jossey-Bass. United States of America.

Mahrum, Mochtar. 2009. English Language In Indonesian Schools In The Era Of Globalization. Tadulako University.

Mc Milan, James H. and Schumacher, Sally. 2010. Research in Education Evidence-Based Inquiry. Pearson Education. Inc. New Jersey.

National Association for Bilingual Education. (1992).

Professional standards for the presentation of bilingual/multicultural teachers. Washington, DC: Author.

Oladejo, James. 2006. Parents'Attitudes Towards Bilingual Education Policy in Taiwan. National Kaohsiung Normal University.

Pérez, B. (2004). Becoming biliterate: A study of two-way bilingual immersion education.

Mahwah, NJ: Lawrence Erlbaum Associates.

Ramirez, A. G. (1985). Bilingualism through schooling. Albany: State University of New York Press.

Senesac, B. K. (2002). Two-way bilingual immersion: A portrait of quality schooling. Bilingual Research Journal, 26, 85-101.

Slavin, Robert E. 2009. Education Psychology: Theory And Practice $9^{\text {th }}$ Ed. Pearson Education Inc. New Jersey.

Sugiyono. 2011. Metode Penelitian Pendidikan Pendekatan Kuantitatif, Kualitatif, dan $R \mathcal{E} D$. Alfabeta. Bandung.

TESOL. 2010. Position Paper on Language and Literacy Development for Young English Language Learners (ages 3-8). Cited from http://www.tesol.org/docs/p df/371.pdf?sfvrsn=2

The Centre for Literacy. 2008. ESL and Literacy: Finding Common Ground, Serving Learners' Needs. Cited from: http://www.nald.ca/library/r esearch/esl_lit/est_lit.pdf

Thomas, W. P., \& Collier, V. P. (2002). A national study of school effectiveness for language minority students' long-term academic achievement. Santa Cruz, CA: Center for Research on Education,Diversity and Excellence. 
Thompson, Linda W. 2004. Literacy Development for English Language Learners: Classroom Challenge in the NCLB Age. Cited form

Unesco. 1990. Evaluating a Literacy Training Program. Bangkok: Unesco Principal Regional
Office for Asia and the Pacific.

Worthen, et.al. 1997. Program Evaluation: Alternative Approaches and Practical Guidelines, Second Edition. Longman Publisher. USA. 